\title{
Strategy Use and Language Performance by Second Language Learners in Nigeria
}

\author{
Laz Chinedu Ogenyi \\ The Use of English Unit, School of General Studies, University of Nigeria, Nsukka, Nigeria \\ Email: cepperngo@gmail.com
}

Received 10 January 2015; accepted 13 June 2015; published 16 June 2015

Copyright (C) 2015 by author and Scientific Research Publishing Inc.

This work is licensed under the Creative Commons Attribution International License (CC BY). http://creativecommons.org/licenses/by/4.0/

(c) () Op Open Access

\section{Abstract}

It is commonly believed that Nigerian students perform very poorly in the English language. Many reasons adduced to be the causative variables for students' poor performance in the English language are located away from the students themselves. What the above scenario portends is that no effort has been made to find out the strategies which the students themselves use in their efforts to learn the English language; it also implies that no effort has been made to find out the relationship between such strategies and the level of students' performance in the target language. The problem which this study addressed was not only to evaluate the language learning strategies which the sampled study population use in their efforts to learn English, but also to determine the extent to which their mean achievement scores in English depend on their use of various language learning strategies. The study was carried out using a descriptive survey research design. Its population consisted of Senior Secondary School (SSS) form II students in three states of south-eastern Nigeria. Random sampling technique was used to select a total of one thousand, four hundred and one (1401: 747 = males, 654 = females) students used for the study. Two sets of instrument were used to collect data for the investigation: appraisal instrument (cloze test), and questionnaire. Two research questions and corresponding two null hypotheses were formulated to guide the study. Results of the study revealed that 1) the greatest proportion of the Igbo learners of English in SSS II (84.3\%) made use of socio-affective language learning strategy, while cognitive strategy had the lowest proportion of users (50.9\%); 2) there was a significant difference, in the English language performance, between the users and non-users of the various language learning strategies.

\section{Keywords}

English Language Learning, Igbo Language Learners, Strategy Use and Language Performance, Second Language Learners in Nigeria 


\section{Theoretical Background/Introduction}

In the literature, different scholars use various terms to refer to the concept: learner strategies, learning strategies, and language learning strategies (http://iteslj.org/Articles/Lessard-Clouston-Strategy.html). These terms are used interchangeably in this work. Generally speaking, strategies are specific plans and methods of approaching a problem or task. Attempts to define learning strategies are situated in psychology, within the theories of cognition. In the context of language learning, researchers have defined language learning strategies as the thoughts and actions of learners who are attempting to increase their learning comprehension, and retention (Rivera-Mills \& Plonsky, 2007: p. 1). Nunan has posited that language learning strategies are the mental and communicative procedures learners use in order to learn and use a language (171). Lessard-Clouston explains language learning strategies as "specific actions, behaviour, steps, or techniques that students (often intentionally) use to improve their progress in developing second language skills" (12).

It is apparent from the foregoing that language learning strategies have to do with the input learners of a language make in order to comprehend, store, retrieve, process, and use linguistic data. Drawing from the above, I define language learning strategies as the goals, conscious and unconscious mental actions, language acquisition processes, skills, learning plans which second language learners adopt in their efforts to acquire and use their second language. Learner strategies are thus performance-related, application-specific, subject to different levels of achievements, and usually lead to language learning success. Experts such as Lessard-Clouston (1997), Ellis (2005), and Steinberg and Sciarini (2006) are in accord that successful language learners frequently use the following components of strategies: verification, inductive processing, deductive reasoning, practice, memorization, and monitoring.

Different researchers have sought different tags to classify learner strategies. The categorization seems to revolve from social, linguistic, creative, and meta-cognitive to affective, compensation and socio-affective strategies. Learner characteristics inherent in cognitive strategies, according to Otagburuagu quoting O’Malley and Chamot, include:

Repetition, resourcing, translation, grouping, deduction, recombination, imagery, auditory representation, key word, contextualization, elaboration, transfer, (and) inferencing (English as a Second Language, 108110).

Meta-cognitive strategies involve functional planning, and thinking about production and comprehension. In addition, learners who use these strategies are said to be engaged in directed and selective attention, self-management and monitoring, delayed production, note-taking and self-evaluation. Research by renowned figures in the field gave rise to a new group of learner strategies referred to as socio-affective strategies- those that take consideration issues such as co-operation, classroom interaction, question for clarification, and learning environment (Cohen 1; O’Malley \& Chamot, cited in Otagburuagu (1999) English as a Second Language, 110; Rivera-Mills \& Plonsky, 2007: pp. 1-2). Nunan's (1991) classification of language learning strategies followed a different slant from those of the other scholars before him. He matched each of the five categories of his learner strategies with macro and micro-skills, and in some cases gave examples of tasks. The five categories of Nunan's language learning strategies include:

\subsection{Strategy Skills Involved}

1) Cognitive —classification, predicting, inducing, taking notes, concept mapping, inferencing, discriminating, and diagramming;

2) Interpersonal—co-operating, and role-playing;

3) Linguistic - conversational patterns, practicing, using context, summarizing, selected listening, and skimming;

4) Affective-personalizing, self-evaluating, reflecting; and

5) Creative-brainstorming.

David Nunan qtd. in Otagburuagu, E. J. English as a Second Language: A Perceptual Approach. Owerri: Intercontinental Educational Books \& Publishers, 1999, 111-114).

Two other features that make Nunan's language learning strategies distinctive are: firstly, his linguistic skills mean the same thing as language skills, because the characteristics of this type of LLS, and their tasks relate more to listening, speaking, reading, and writing. Secondly, brainstorming is given a special status by categoriz- 
ing it as a creative strategy.

Oxford differentiates between direct and indirect strategies, which she sorts into six separate sets. Under the direct strategies, she lists:

Memory, which creates mental linkages, and assists in entering information into long-term memory, and retrieving same when needed for communication;

Cognitive, which is used for forming, analyzing, and revising internal mental models and for receiving and producing messages in the target language; and

Compensation strategy, which is employed for guessing; it is also needed to overcome any gaps in knowledge of the target language (http://iteslj.org/Articles/Lessard-Clouston-strategy.httml).

Under the indirect strategies, she classifies:

Meta-cognitive: This helps learners “execute control” through planning, arranging, focusing, and evaluating their learning;

Affective which is adopted when one wants to encourage one's self. It also enables learners to control feelings, motivations, and attitudes related to language learning. In the opinion of Macaro (2006), affective strategy requires the knowledge of oneself as a learner through recurrent monitoring of one's learning (328); and

Social strategy constitutes Oxford's third type of indirect LLS. It facilitates interaction with others. Within social strategy is found such features as asking questions, co-operating and empathizing with others (Oxford, cited in Lessard-Clouston, 4).

It is therefore obvious that language learning strategies, especially when used by informed students, place students at the centre of the second language classroom enabling them to make pedagogically sound decisions concerning their own learning. One can rightly assert that language learning strategies are facilitative criteria for language learning, especially in second language situations.

The general feeling of the majority of stakeholders in the education sector in Nigeria is that students' performances in both internal and external examinations are not only poor, but reprehensible. Osakwe (1998/99) corroborates this fact when she succinctly writes:

In recent time in Nigeria, it has been discovered that adolescents do not perform as well as they should in school... Several research findings have actually shown that students perform very poorly in English... In a research conducted by Prof Akere... of the University of Lagos, it was discovered that out of 195,840 students who sat for English in the West African Examinations Council's SSCE of a particular year, only $12,383(6.3 \%)$ had a credit pass in the subject (138-139).

The general poor performance, in the researcher's thinking, implies that students are not competent in the English language. This view is informed by a commonly held belief that competence in the English language skills enhances students' good performance in English and other subjects. Reading, one of the four language skills, is regarded as a tool skill in the sense that a child's progress in other subjects depends substantially on his reading ability (cf. Nwosu-Izuwa, 2002; Ezeokoli, 2004; Ogenyi, 2008b). Osakwe (1998/99) cites Mohammed’s study of Senior Secondary School Certificate Examination results of a five-year period where it was observed that there was an alarming close correlation between failure in English and failure in the other subjects. Mohammed was quoted to have observed that the correlation "seems to lend strong support that many failures in subjects are really failures in English” (Mohammed qtd. in Osakwe, 1998/99: p. 139).

The World Bank (1995) report, in addition to Osakwe's reason (1998/99) for students' poor performance, locates the following as the causative variables in the low level, in performance, of Nigerian students and graduates: inadequate financing, insufficient and irrelevant learning materials, including old and outdated equipment, books and journals, poorly trained and paid teaching staff, unplanned expansion of enrolment leading to over-supply of graduates, and irrelevant curriculum. Results of other studies point to the curriculum designers and implementers, policy makers, decay in the educational sector, incessant closure of universities, and strikes among others, as the causes of students’ poor performance (Kolapo, 2008: p. 1; Akwanya, 2; Onukaogu, 2002: pp. 182-183; Otagburuagu (1997), Teaching and Learning, 4).

What the above scenario portends is that the causative variables are located away from the students themselves. There has been no effort, as far as this researcher knows, to find out how the students themselves try to acquire the target language, English, and according to Firth and Wagner, one of the ways of approaching the study of second language acquisition is to understand how non-primary acquisition takes place (789). This calls attention to the language learning strategies (LLS) which the Nigerian students use in their endeavour to learn 
and use the English language in their second language environment. This is important because scholars in the field believe that learners who fail to do well in language learning have been known to adopt bad language learning strategies (Cohen, 1; Lessard-Clouston, 2; Nunan, 171; Rivera-Mills \& Plonsky, 2007: pp. 3-4). There is paucity of research on the assessment of the strategies students of Igbo origin use in learning their second language (L2), and also on the relationship between such strategies and the level of the students' performance in the English language.

Even though the World Bank (1995) study identified major areas of the decline in the university education, the real problem may have its roots at the Senior Secondary School level, especially when one considers such critical issues as transfer of training and learning. Based on this, it becomes reasonable for research efforts to be rigorously directed on this level of learners. The necessity of this is highlighted by the fact that it is at this level that the potential undergraduates are given adequate foundation in the use of English. In addition, an evaluation of learners' strategy repertoire is an important measure which will help both the teachers and learners to know the strategies that are useful and effective for particular language tasks, thereby increase the learners' learning potential, autonomy, and overall success.

\subsection{Problem of the Study}

The problem which this study addressed was not only to determine the percentage of the Igbo learners of English who were in SSS II in south-eastern Nigeria that made use of different language learning strategies; the study further ascertained the extent to which the mean achievement scores, in English, of Igbo learners of English in SSS II depended on their use of various language learning strategies.

\subsection{The Study Design}

The procedure that was adopted in this study is consistent with the features of survey research, which is defined as: "The method of collecting information by asking a set of pre-formulated questions in a predetermined sequence in a structured questionnaire to a sample of individuals drawn from a defined population so as to be representative of that population" (www.mori.com/rmu/glossary.shtml).

To guide the study, two research questions were designed as follows:

\section{Research Question 1:}

What proportion of the Igbo learners of the English language in Senior Secondary School II (SSS II) uses the various language learning strategies (LLS) in learning English as a second language?

\section{Research Question 2:}

To what extent do the mean achievement scores in the English of the Igbo learners of English in SSS II depend on their use of various language learning strategies?

Arising from the foregoing, and also to guide the investigation, the following null hypotheses were formulated:

Ho1: There is no significant difference between the proportion of the Igbo learners of English who use the various language learning strategies and those who do not use them.

Ho2: There in no significant difference between the mean achievement scores in the English language of the Igbo learners of English who use various language learning strategies and those who do not.

\subsection{The Study Population and Sampling Procedure}

The study population consisted of the same Senior Secondary School (SSS) form II students that the researcher used in an earlier published study. This study and that one were carried out simultaneously in three (3) out of the five (5) States of south-eastern geopolitical Zone of Nigeria. The three States-Ebonyi, Enugu, and Imo-were purposively chosen. They were considered, as it were, true representatives of the two (2) old Igbo StatesAnambra and Imo. Enugu and Imo States represented the old Anambra and old Imo States respectively; Ebonyi is an offshoot of communities drawn from both the old Anambra and old Imo States. There are similarities in the educational systems and attitudes towards education in these states. Typically, education is highly prized. High value is placed on effort, which is viewed as being directly linked to high education achievement (cf. Grant \& Dweck, 2001; Woodrow, 2006).

Senior Secondary School form II (SSS II) students were considered appropriate for the study, because they 
were very close to "examination class": it was expected that the period of anticipation of moving to the final stage of secondary school examinations would predispose them to using more strategies, other things being equal.

Twelve (12) schools, four (4) each, were randomly sampled from the three selected States. Two of the sampled schools in each State were government owned and the other two privately owned. Two of such schools were also randomly sampled from both urban and rural areas of each of the chosen States.

The study used the proportionate stratified random sampling technique in sampling students from the above mentioned states and student cohort. However, the sampling technique was used only in schools where the population of the SSS II students was more than one hundred (100). All the SSS II students in schools where the students' population was less than one hundred were used; seven schools fell under this category. These criteria gave rise to a total of one thousand, four hundred and one (1401) students that were used for the study, comprising seven hundred and forty-seven (747) males and six hundred and fifty-four (654) females (Table A1). Their ages ranged between fifteen (15) and nineteen (19) years with an average of seventeen (17) years.

\subsection{Research Instruments}

\section{Design of the Instruments}

Two sets of instruments were used to collect the data for the investigation. One of the instruments was appraisal instrument which was in the form of cloze test. Cloze tests measure the readers' ability to decode "interrupted" or "mutilated" messages by making the most acceptable substitutions from all the contextual clues available. Decoding is a well known feature of proficient reading. The cloze test questions incorporated relevant topics in the Senior Secondary School II English language syllabus in the area of the study. In constructing the questions, I considered their objectivity, clarity, and suitability to the level of students. The questions tested the mean achievement scores of the sampled students on reading skill. The design was cognizance that there were some other language skills, but chose reading skill, because of all the language skills, reading can be regarded as a "tool skill”, in the sense that a learner's progress in other language skills depends considerably on his ability to read. Reading and writing are higher order language skills, but the former occupies the most important position in language learning. Ezeokoli agrees with this point when he writes: "In spite of the multiple or elastic meaning of literacy, reading and writing remain basic literacy skills for acquiring other literacy skills; but perhaps reading stands out as the most basic (sic) tool for learning and human survival” (318). Reading experts describe the concept variously. In the opinion of Gwete, reading is “... the gateway to education...” (32); Onukaogu (2002) describes it as "the fulcrum of literacy" (292). Dike also avers that "... reading is not only the best but also the only way to master a language, whether it is a first or second language. Through wide reading, individuals build foundations for independent learning and gain awareness of the broad uses of reading for information and pleasure” (17).

It is therefore obvious that learners who cannot, and do not read will not get educated linguistically, because in addition to the facts fore stated, "Reading helps to keep the individual on a pedestal in which he vicariously enters the textual world of authors, and shares the diversity of experiences embodied in such works” (Ogenyi, 137). Increase in both the depth and breath of vocabulary knowledge needed for unambiguous oral and written expressions depends on reading. In addition to developing vocabulary, reading helps the reader/learner to make inferences, classify issues, observe situations, criticize matters, identify relationships, differentiate styles, draw conclusions, and make generalizations all of which are needed in effective learning and use of the English language in a second language environment. Based on the foregoing significant roles of reading over the other three language skills, it was considered a more appropriate skill for assessing the study subjects.

The cloze test instrument which was used for the study had the features of the structuralist, the integrative, and the communicative approaches to testing. One of the characteristics of the structuralist approach to testing is that "the skills of listening, speaking, reading, and writing are... separated from one another... because it is considered essential to test one thing at a time” (Heaton, 1988: p. 15). Again, reliability forms an integral part of structuralist testing. Although integrative tests do not seek to separate language skills into neat divisions in order to improve test reliability, they "are best characterized by the use of cloze testing" (Heaton, 1988: p. 16); thus, lies their relevance in this study. Like the structuralist approach to testing, communicative tests do measure different language skills. The attempt to measure different language skills is based on a view of language referred to as "the divisibility hypothesis" (Heaton, 1988: p. 19). It is further explained that communicative testing re- 
sults in an attempt to obtain different profiles of learners' performance in the language, which also explains its usefulness in the present study. Communicative evaluation also emphasizes on test contents to be totally relevant for a particular group of testees. This criterion was met by the test items used in this study, since they were drawn from the Senior Secondary School form II English language syllabus.

The second instrument was questionnaire the contents of which elicited responses on the participants' use of the various language learning strategies (LLS) of Oxford and Burrystock's (2008) standardized Strategy Inventory for Language Learning (SILL) (http://homepage.wtuc.edu.tw/sill.php) which was used for the study. The questionnaire items addressed issues that boarder on cognitive, linguistic, meta-cognitive, affective, compensation, and socio-affective language learning strategies in that order. Self-reporting data on the use of these language learning strategies were collected from the sampled population used for the study. The use of questionnaire to elicit the participants' strategy use is validated by Macaro's assertion as follows:

The methodology for eliciting learner strategy use... is at an acceptable level of validity and reliability. Questionnaires... provide the broad picture... and effectively yield insights into skill-specific or task-specific strategy use... The claims of effectiveness are made by both L2 researchers and by researchers operating in other fields related to cognitive processing (321).

\section{Elicitation Technique}

Both the elicitation task mode and elicitation task focus were used to gather data on the student's language performance ability. The task mode was reading. The subjects were required to read and answer (respond to) cloze test questions. The task focus was on both natural communication task and linguistic manipulation task. The natural communication task tested the participants' subconscious use of the grammar rules required to convey an idea or a message. The linguistic manipulation task was, on the other hand, used to focus the subjects' attention on performing conscious linguistic manipulation; i.e., to test the students' meta-linguistic awareness, or their conscious knowledge and manipulation of the rules and forms of the English language. The tasks (communicative $\&$ manipulative) were structured, since the researcher intended to ask specific questions in order to elicit target linguistic knowledge within a limited time span. It is important to note that the usage of these tasks is interrelated, as none is used in complete exclusion of the other.

\subsection{Validation of the Research Instruments}

Face and content validities of the appraisal instruments and the questionnaire were established. Practitioners knowledgeable in the field of second language learning examined, read, made suggestions and certified that the instruments were indeed appropriate and reflected their various intents.

Also, the use of SSS II English language syllabus for the data base of the appraisal items/questions added to the content validity. The questions were unambiguous, and this made them answerable in a dichotomous manner; that, too, contributed to the items' validity.

\subsection{Administration of the Study Instruments}

The administration of the research instruments on the study subjects took place towards the end of the schools' second term of 2008/2009 academic session. However, the time and dates of administration varied at different schools. On arrival at each school, I went to the Principle, introduced myself and my mission. Some of the school authorities demanded to go through the instruments before allowing their administration on their students.

The administration of the instruments took place during school period and under examination condition: I distributed the instruments, waited on the students to respond to the questionnaire and answer the cloze test questions, and collected the instruments after one hour, twenty minutes. This led to no loss of the instruments distributed. In some of the schools where I did not arrive on time, I had to wait for the students to finish the examination they had already begun to write before my arrival. The administration of the instruments lasted for four weeks.

\subsection{Method of Data Analysis}

As was done in the earlier published study that was executed at the same time with this one, the scores of the in- 
dividuals on the various items were summed up for each sub-scale of the inventory. The means and standard deviations of the scores were computed for each sub-scale and used to analyse the data for the two research questions. A variety of statistical tools was used in testing the two corresponding null hypotheses at 0.05 levels of significance. Specifically, chi square test of significance was used to test hypothesis 1. A two-way analysis of variance (ANOVA) test was run to test the data that were generated for, and used in hypothesis 2.

\subsection{Data Presentation and Interpretation}

The results of the data that were collected are presented and interpreted hereunder:

\section{Research Question 1:}

What proportion of the Igbo learners of the English language in SSS II uses the various language learning strategies in learning English as a second language?

Table 1 shows that the order of decreasing use of the various language learning strategies is socio-affective, meta-cognitive, affective, linguistic, compensation and cognitive with their respective mean ratings (MRs) of 84.3, 79.8, 57.7, 57.5, 51.9 and 50.9. In other words, the greatest proportion of students (84.3) uses socio-affective language learning strategy, while the least proportion (50.9) uses cognitive. The table indicates that four of the strategy types - cognitive, linguistic, affective, and compensation are averagely used with the mean ratings of $50.9 \%, 57.5 \%, 57.7 \%$ and $51.9 \%$ respectively.

\section{Research Question 2:}

To what extent do the mean achievement scores in English of the Igbo learners of English in SSS II depend on their use of the various language learning strategies?

Evidence in Table 2 shows that the mean achievement score for the students who use cognitive language learning strategy is 46.49 , as against 30.81 for those who do not make use of the same strategy. For those who use linguistic language learning strategy, it is 45.62 against 29.56 for those who do not use it; for meta-cognitive, it is 39.10 for those who use it as against 37.55 for the non-users; for affective, it is 45.65 for those who use as against 29.41 for those who do not use it; for compensation, 45.11 for those who use as against 31.98 for those who do not use; and for socio-affective, it is 39.69 for those who use as against 33.95 for those who do not use it. In other words, there appears to be consistent difference between those who use and the students who do not make use of each of the various language learning strategies, suggesting that the mean achievement scores in English appear to be dependent on the use of each of the language learning strategies.

\section{Ho1:}

There is no significant difference between the proportion of the Igbo learners of English who use the various language learning strategies and those who do not use them.

As observed in Table 3, the number of users of:

1) Cognitive language learning strategy is 713 as against 688 for those who do not use it. This represents $50.9 \%$ of the sampled population as shown in Table 1 . The chi square in respect of this value which is 0.446 at 1 df. is not significant at 0.05 levels.

2) Linguistic language learning strategy is 805 for the users, as against the 596 for those who do not use it. This represents $57.5 \%$ of the study subjects as shown in Table 1 . The chi square in respect of this value which is 31.18 at $1 \mathrm{df}$. is significant at 0.05 levels.

3) Meta-cognitive language learning strategy is 1118 for the users, as against 283 for those who do not use the strategy. This represents $79.8 \%$ of the study population as shown in Table 1 fore presented. The chi square in respect of this value which is 497.66 at $1 \mathrm{df}$. is significant at 0.05 levels.

4) Affective language learning strategy stands at 809 for the users against 592 for the non-users. This represents $57.7 \%$ of the students as shown also in Table 1 . The chi square in respect of this value which is 36.61 at 1 df. is significant at 0.05 levels.

5) Compensation language learning strategy is 727 for those who use the strategy as against 674 for those who do not use it. This represents $51.9 \%$ of the study sample as shown in Table 1 . The chi square in respect of this value which is 2.01 at $1 \mathrm{df}$. is not significant at 0.05 levels.

6) Socio-affective language learning strategy is 1181 and 220 for those who use the learner strategy and those who do not use it respectively. This represents $84.3 \%$ of the students used for the study as shown in Table 1. The chi square in respect of this value which is 659.19 at $1 \mathrm{df}$. is significant at 0.05 levels.

From the foregoing, it is seen that for the compensation and cognitive language learning strategies, the difference between the proportion of the users and non-users, in each case, is not significant. In other words, the 
Table 1. Proportion/percentage of Igbo learners of English who uses the various language learning strategies (LLS).

\begin{tabular}{ccc}
\hline Types of LLS & Number of users & Percentage \\
\hline Cognitive & 713 & 50.9 \\
Linguistic & 805 & 57.5 \\
Meta-cognitive & 1118 & 79.8 \\
Affective & 809 & 57.7 \\
Compensation & 727 & 51.9 \\
Socio-affective & 1181 & 84.3 \\
\hline
\end{tabular}

Table 2. Mean achievement scores of Igbo learners of English that use the various language learning strategies (by use/do not use of LLS).

\begin{tabular}{cccc}
\hline & & \multicolumn{2}{c}{ Mean achievement scores } \\
\cline { 3 - 3 } & & Use & Do not use \\
\hline \multirow{2}{*}{ Types of LLS } & Cognitive & 46.49 & 30.81 \\
& Linguistic & 45.62 & 29.56 \\
& Meta-cognitive & 39.10 & 37.55 \\
& Affective & 45.65 & 29.41 \\
& Compensation & 45.11 & 31.98 \\
\hline
\end{tabular}

Table 3. Chi square test of the proportion of Igbo learners of the English language in SSS II that makes use of the various language learning strategies.

\begin{tabular}{|c|c|c|c|c|c|c|c|}
\hline Types of LLS & Use/do not use & Observed & Expected & Chi square & Df & Sig. & Sig. @ 0.05 level \\
\hline \multirow{2}{*}{ Cognitive } & Use & 713 & 700.50 & \multirow{2}{*}{0.446} & \multirow{2}{*}{1} & \multirow{2}{*}{0.504} & \multirow{2}{*}{ Not Sig. } \\
\hline & Do not use & 688 & 700.50 & & & & \\
\hline \multirow{2}{*}{ Linguistic } & Use & 805 & 700.50 & \multirow{2}{*}{31.18} & \multirow{2}{*}{1} & \multirow{2}{*}{0.00} & \multirow{2}{*}{ Sig. } \\
\hline & Do not use & 596 & 700.50 & & & & \\
\hline \multirow{2}{*}{ Meta-cognitive } & Use & 1118 & 700.50 & \multirow{2}{*}{497.66} & \multirow{2}{*}{1} & \multirow{2}{*}{0.00} & \multirow{2}{*}{ Sig. } \\
\hline & Do not use & 283 & 700.50 & & & & \\
\hline \multirow{2}{*}{ Affective } & Use & 809 & 700.50 & \multirow{2}{*}{33.61} & \multirow{2}{*}{1} & \multirow{2}{*}{0.00} & \multirow{2}{*}{ Sig. } \\
\hline & Do not use & 592 & 700.50 & & & & \\
\hline \multirow{2}{*}{ Compensation } & Use & 727 & 700.50 & \multirow{2}{*}{2.01} & \multirow{2}{*}{1} & \multirow{2}{*}{0.16} & \multirow{2}{*}{ Not Sig. } \\
\hline & Do not use & 674 & 700.50 & & & & \\
\hline \multirow{2}{*}{ Socio-affective } & Use & 1181 & 700.50 & \multirow{2}{*}{659.19} & \multirow{2}{*}{1} & \multirow{2}{*}{0.00} & \multirow{2}{*}{ Sig. } \\
\hline & Do not use & 220 & 700.50 & & & & \\
\hline
\end{tabular}

difference between those who use and those who do not use both compensation and cognitive language learning strategies, as earlier observed in Table 1, is real difference which means that the difference is not attributable to chance error. This confirms the earlier observed results in Table 1 where it was seen that the lowest proportion of students uses cognitive language learning strategy followed by compensation strategy. Similarly, in each of the other four language learning strategies-linguistic, meta-cognitive, affective, and socio-affective- -the difference between those who use and those who do not use, as earlier observed, is significant. In other words, the difference is real and not attributable to chance error, nor arose by chance.

Ho2:

There is no significant difference between the mean achievement scores in the English language of the Igbo learners of English who use the various language learning strategies and those who do not.

ANOVA data in Table 4 show that the sum of squares between and within groups respectively of: 
Table 4. ANOVA table of mean achievement scores by use/non-use of the various language learning strategies.

\begin{tabular}{|c|c|c|c|c|c|c|}
\hline Types of LLS & $\begin{array}{l}\text { Sources of } \\
\text { variations }\end{array}$ & Sum of squares & Df & Mean square & Sig. of $F$ & Sig. @ 0.05 level \\
\hline Cognitive & $\begin{array}{l}\text { Between groups } \\
\text { within groups }\end{array}$ & $\begin{array}{c}85990.6022 \\
599658.2814\end{array}$ & $\begin{array}{c}1 \\
1399\end{array}$ & $\begin{array}{c}85990.6022 \\
428.6335\end{array}$ & 0.00 & Significant \\
\hline Linguistic & $\begin{array}{l}\text { Between groups } \\
\text { within groups }\end{array}$ & $\begin{array}{c}88348.86065 \\
97300.0230\end{array}$ & $\begin{array}{c}1 \\
1399\end{array}$ & $\begin{array}{c}88348.8606 \\
426.9478\end{array}$ & 0.00 & Significant \\
\hline Meta-cognitive & $\begin{array}{l}\text { Between groups } \\
\text { within groups }\end{array}$ & $\begin{array}{c}546.8134 \\
685102.0702\end{array}$ & $\begin{array}{c}1 \\
1399\end{array}$ & $\begin{array}{l}546.8134 \\
489.7084\end{array}$ & 0.00 & Significant \\
\hline Affective & $\begin{array}{l}\text { Between groups } \\
\text { within groups }\end{array}$ & $\begin{array}{c}90117.2748 \\
595531.6089\end{array}$ & $\begin{array}{c}1 \\
1399\end{array}$ & $\begin{array}{c}90117.2748 \\
425.6838\end{array}$ & 0.00 & Significant \\
\hline Compensation & $\begin{array}{l}\text { Between groups } \\
\text { within groups }\end{array}$ & $\begin{array}{c}60318.6811 \\
625330.2026\end{array}$ & $\begin{array}{c}1 \\
1399\end{array}$ & $\begin{array}{c}60318.6811 \\
446.9837\end{array}$ & 0.00 & Significant \\
\hline Socio-affective & $\begin{array}{l}\text { Between groups } \\
\text { within groups }\end{array}$ & $\begin{array}{c}6100.7641 \\
679548.1195\end{array}$ & $\begin{array}{c}1 \\
1399\end{array}$ & $\begin{array}{c}6100.7641 \\
485.7385\end{array}$ & 0.00 & Significant \\
\hline
\end{tabular}

1) 85990.6022 (df. 1) and 599658.2814(df. 1399) in respect of the difference in mean achievement scores of the students who use cognitive LLS and those who do not is significant at 0.00 level. For cognitive language learning strategy, this value is significant at 0.05 levels. This then implies that the observed difference in the mean achievement scores of students who use cognitive LLS and those who do not use it is actual difference not attributed to chance error(s).

2) 88348.8606 (df. 1) and 597300.0230 (df. 1399) in respect of the difference in mean achievement scores of the students who use linguistic LLS and those who do not is significant at 0.00. For linguistic LLS, this value is significant at 0.05 levels. This implies that the earlier observed difference in the mean achievement scores of students who use linguistic LLS and those who do not use it is actual difference not attributed to chance error(s).

3) 546.8134 (df. 1) and 685102.0702 (df. 1399) in respect of the difference in the mean achievement scores of the students who use meta-cognitive LLS and those who do not is significant at 0.00 . For meta-cognitive LLS, this value is significant at 0.05 levels. This then implies that the observed difference in the mean achievement scores of students who make use of meta-cognitive LLS and those who do not use it is actual difference not attributed to chance error(s).

4) 90117.2748 (df. 1) and 595531.6089 (df. 1399) in respect of the difference in the mean achievement scores of the students who use affective LLS and those who do not is significant at 0.00 . For affective LLS, this value is significant at 0.05 levels. This then implies that the observed difference in the mean achievement scores of students who use affective LLS and those who do not use it is actual difference not attributed to chance error(s).

5) 60318.6811 (df. 1) and 625330.2026 (df. 1399) in respect of the difference in the mean achievement scores of the students who use compensation LLS and those who do not is significant at 0.00 . For compensation LLS, this value is significant at 0.05 levels. This then implies that the observed difference in the mean achievement scores of students who use compensation LLS and those who do not use it is actual difference not attributed to chance error(s).

6) 6100.7641 (df. 1) and 679548.1195 (df. 1399) in respect of the difference in the mean achievement scores of the students who use socio-affective LLS and those who do not is significant at 0.00 . For socio-affective LLS, this value is significant at 0.05 levels. This then implies that the observed difference in the mean achievement scores of students who use socio-affective LLS and those who do not use it is actual difference not attributed to chance error(s).

From the foregoing, it has been shown that there is a significant difference between study subjects who use each of the language learning strategies-cognitive, linguistic, meta-cognitive, affective, compensation and socio-linguistic - and those who do not use them. This therefore invalidates the hypothesis which says that there is no significant difference between the mean achievement scores in the English language of the Igbo learners of English who use the various language learning strategies and those who do not.

\section{Discussion of Findings}

The results from research question 1 , and hypothesis 1 show that whereas there is no significant difference be- 
tween those who use both cognitive and compensation strategies, there is significant difference between those who use the other four language learning strategies-linguistic, meta-cognitive, affective and socio-affective. The researcher is not utterly surprised at the above result, because in the words of Rivera-Mills and Plonsky, “... even students at low levels of L2 proficiency are meta-linguistically aware of second language acquisition processes to some degree" (4). The results in Table 4 which confirm those in Table 1 that the lowest percentage (50.9\%) of the study population makes use of the cognitive language learning strategy, and that meta-cognitive language learning strategy is the second highest used (79.8\%) contradict the study results of O'Malley and Chamot's (1990) that beginning and intermediate-level ESL students use cognitive strategies more frequently than meta-cognitive ones.

Part of the implications of the above results is that a little above the average number of the study population makes use of the skills involved in the language learning strategies such as functional planning, extensive reading, selective attention and listening, question for clarification, note-taking, self-management and monitoring/ self-evaluation, classification, practising, summarizing, predicting, using context, reflecting, guessing, among others.

The results of the chi square test failed to validate the first hypothesis. This has led me to conclude that there is significant difference between the proportion of the Igbo learners of English who use the various language learning strategies and those who do not use them. It is also apparent that linguistic strategies are minimally used. This is a dangerous trend especially when one recalls that the greatest source of information about any language is the language itself: the tenets of linguistic strategies are, in the main, akin to language skills of listening, speaking, reading and writing.

Experience of the researcher shows that many students in Nigeria believe in what one would like to describe as language myth: believing-erroneously-that English is a subject that one does not need to read. The researcher had, on several occasions especially when examinations were approaching, overheard students say/ask: “English cannot be read/How can you read English?” These highlight the fact that students' strategies usage reflects their underlying beliefs about how the English language is learned.

The least proportion of the study population recorded for the use of cognitive strategy (50.9) suggests that the students have low aptitude.

Research question 2 intended to uncover the extent to which the mean achievement scores in English of the Igbo learners of English in SSS II depended on their use of the various language learning strategies. It is discovered that the mean achievement scores of the study population who use cognitive, linguistic, meta-cognitive, affective, compensation, and socio-affective language learning strategies stand at 46.49, 45.62, 39.10, 45.65, 45.11, and 39.69 respectively, as against the mean achievement scores for the students who do not use the same strategies which are 30.81, 29.56, 37.55, 29.41, 31.98, and 33.95 in that order. It is evident from the above results that those who use the language learning strategies perform better than those who do not. This implies that good performance in English depends on the use of the various language learning strategies. Cohen and Shively's comment corroborates this result: "Research on the immigrant students in the study-abroad context/programme support the notion that strategy use can promote second language learning” (193). The results of the ANOVA which was used to test hypothesis 2 show that there is also a consistent difference, in performance in the English language, between the users and non-users of the various language learning strategies. The results entail that the null hypothesis (i.e., Ho2) could not be sustained.

These findings are not totally strange. My expectation that the study sample should have high mean achievement scores is premised on the contention by earlier researchers that "meta-cognitive strategies," which received the second highest percentage usage score (Table 1), "are more predictive of high academic performance..." (Garcia \& Pintrich cited in Woodrow, 229). Results of previous research have not also disputed the fact that learners who use language learning strategies perform better than those who do not. If those who used the various language learning strategies, in this study, did not perform better, one would question the efficacy of the characteristics of the language learning strategies discussed in the introduction of this work. The results of this study, therefore, do not contradict those of Rodgers (2006) whose research results reveal that those who know and use language learning strategies exhibit improved functional linguistic abilities, as measured by his study's cloze test passage, than those who neither know nor use the strategies (381).

Although those who use, or claim to use, the learner strategies in this study have better achievement mean scores than those who do not, the general low mean achievement scores they recorded is worrisome: Whereas the passing grades recorded by those who made use of the various language learning strategies do not reach av- 
erage marks (46.49, 45.62, 45.65, and 45.11), others in this group failed to get passing grades (39.10 and 39.69 ). Intuitively, these results which indicate general poor mean achievement scores, in the English language, are unexpected. It was expected that the study subjects' achievement scores should be higher since they claimed that they make use of the various learning strategies, which are said to facilitate and promote language learning and language proficiency. Their low mean achievement scores might have resulted from their not using the language learning strategies appropriately, or they were using what Otagburuagu calls "bad strategies” which he says lead learners to handle tasks erroneously and block the acquisition of proper linguistic data for the development of language skills (English as a Second 1). Scholars in the field believe that learners who fail to do well in language learning have been known to adopt bad language learning strategies. I hypothesize that the low mean achievement scores could also be due to low IQ (aptitude) level of the sampled study subjects. It could again be attributed to their earlier stated unwholesome attitude to second language learning.

The findings here are consistent with those of the studies conducted by Cohen and Shively (2007), Woodrow (2006) and Vandergrift (2003). The study population of each of these researchers comprised subjects who were in the native language environment. By using a sample population who were in a second language environment, the present study has broken new grounds.

\section{Conclusion}

The results of this study add to and confirm the literature in second language learning concerning the central role of language learning strategies in learning process and language proficiency. In other words, they support the hypothesis that the use of learner strategies usually leads to language learning success, and that successful language learners constantly employ language learning strategies.

The results of the study also reveal that:

1) The greatest proportion of the Igbo learners of English in SSS II (1181, i.e., 84.3\%) makes use of socioaffective language learning strategy; this may be due to the many social practices prevalent in the area of the study. Meta-cognitive learner strategy is the second highest in use with 1118 users representing 79.8\%. Cognitive strategy has the least proportion of the study population that makes use of it (713, i.e., 50.9\%). A little above the average number of the study subjects uses each of the other three language learning strategieslinguistic (805, 57.7\%), affective (809, 57.7\%), and compensation (727, 51.9\%);

2) There is significant difference, in the English language performance, between the users and non-users of the various language learning strategies. The former group performed better than the latter group in the cloze test used for this study. Although this particular result confirmed the generally held view that those who make use of language learning strategies perform better in language learning and language performance than those who do not, it also revealed a perplexing phenomenon: the mean achievement scores recorded by those who used the various language learning strategies are abysmally low. The passing grades recorded by those who used cognitive, linguistic, affective, and compensation strategies stand at 46.49\%, 45.62\%, 45.65\%, and 45.11\%, while those who used meta-cognitive and socio-affective strategies failed to score passing grades as their mean scores stand at $39.10 \%$ and $39.69 \%$ respectively. This is, to say the least, below standard. Consequent on the above, I feel that this study has not only contributed significantly to the literature of Applied Linguistics, but has also carved a niche for itself in the world of scholarship by discovering that:

The inappropriate use of the various language learning strategies by the Igbo learners of English in southeastern geo-political zone of Nigeria is a predictor and/or factor that gives rise to their poor performance in the English language.

From the foregoing, the study has helped me to conclude that:

1) There is converse use of strategies (CUS) by the study subjects;

2) There is converse relationship between performance and strategies usage by the study group; and

3) Aberration in strategies application (ASA) results in low language performance (LLP).

\section{Recommendations}

Predicated on the findings of this study, the following recommendations are offered:

First and foremost, it should be considered a matter of urgency to develop and use language learning strategies materials for colleges of education and university classes, since it is not certain that the English language 
teachers in secondary schools, in Nigeria, themselves know these strategies. Writers of textbooks should deliberately and copiously incorporate language learning strategies into their works.

In addition, teaching and learning of language learning strategies should be introduced into a variety of secondary school classes for the second language students. The results of Vandergrift's (2006) study suggest, among other things, that students may and do benefit from strategy instruction and that such training does reduce the gap in transfer of first language inferencing skills to second language inferencing tasks (15). The training will provide avenues for the students to begin to:

1) Learn how to learn English;

2) Appreciate the relevance of learner strategies for language learning tasks;

3) Understand:

- What language resources/tools are available to them,

- What specific language learning strategies they might use in order to improve their own vocabulary acquisition and use, grammar rules and use, and (second) language skills of listening, speaking, reading and writing, and

- Which learner strategies are most appropriate for which learning tasks.

Teachers of English should begin to:

- Look at what their students are doing in the process of learning the language,

- Look at how students deploy language resources in social situations,

- Be interested in their students' "social cognition”, i.e., what the students do, think, demonstrate, manipulate, achieve, acquire, and learn during concerted social interactions,

- Study their teaching contexts, paying attention to their materials, and

- Be interested in knowing whether their students often ask questions for clarifications, or corrections, and whether they cooperate with their peers or seen to have much contact outside of class with proficient second language users.

There should be learner reflection; i.e., students themselves should form the habit of self-reflection on their language learning and language learning strategies usage both during and after the LLS training in the class. Graham emphasizes the importance of this when he writes: "For learners, a vital component of self-directed learning lies in the on-going evaluation of the methods they have employed on tasks and of their achievements within the... programme" (170). Learner reflection is important, because language learning strategies obviously involve individual's unique cognitive, social, linguistic, and affective learning styles and strategies.

As a result of the general belief that first language provides the platform for successful second language learning, development of the mother tongue should be encouraged, so that it can promote cognitive development and act as a base for learning the second language_English—in Nigeria. Onukaogu's views (2002), as embodied in the following passage, underscore the point being made:

Literacy in English and other tongues would be richly enhanced if the foundations of our children's literacy are our children's mother tongues. Those of us, who underrate the role of the mother tongue in the literacy acquisition of the Nigerian child, clip the wings of the child and make the child unable to fly ("Reading for the Attainment...” 292).

\section{References}

Akwanya, A. N. (2007). English Language Learning in Nigeria: In Search of an Enabling Principle. Inaugural Lecture, University of Nigeria, Nsukka.

Cohen, A. D. (1998). Strategies in Learning and Using a Second Language. London: Longman. http://www.tesl-ej.org/ej12/r10.html

Cohen, A. D., \& Shively, R. L. (2007). Acquisition of Requests and Apologies in Spanish and French: Impact of Study Abroad and Strategy-Building Intervention. Modern Language Journal, 91, 189-212. http://dx.doi.org/10.1111/j.1540-4781.2007.00540.x

Ellis, R. (2005). Measuring Implicit and Explicit Knowledge of a Second Language: A Psychometric Study. Studies in Second Language Acquisition, 27, 141-172. http://dx.doi.org/10.1017/S0272263105050096

Dike, V. W. (2003). Portable Libraries as Vehicle for Literacy Development: A Library Service to Pupils and Prisoners in Nigeria. In A. E. Arua (Ed.), Reading for All in Africa: Building Communities Where Literacy Thrives (pp. 17-22). USA: International Reading Association. 
Ezeokoli, F. O. (2004). Voluntary Reading Interests and Achievement in Reading Comprehension among Senior Secondary Students in Ibadan Nigeria. Literacy and Reading in Nigeria, 10, 317-324.

Firth, A., \& Wagner, J. (2007). Second/Foreign Language Learning as a Social Accomplishment: Elaborations on a Reconceptualized SLA. Modern Language Journal, 91, 800-818. http://dx.doi.org/10.1111/j.1540-4781.2007.00670.x

Graham, S. (1997). Effective Language Teaching. Clevedon: Multilingual Matters.

Grant, H., \& Dweck, C. S. (2001). Cross Cultural Response to Failure: Considering Outcome Attributions with Different Goals. In F. Salili, C. Chiu, \& Y. Y. Heng (Eds.), Student Motivation: The Culture and Context of Learning (pp. 203-219). New York: Plenum. http://dx.doi.org/10.1007/978-1-4615-1273-8_10

Gwete, W. B. (1987). Reading for Functional Literacy. In S. L. James (Ed.), Reading for Career Development (RAN Monograph Series C) (pp. 35-53). Ibadan: Reading Association of Nigeria.

Heaton, J. B. (1988). Writing English Language Tests: Longman Handbook for Language Teachers (New Edition). London: Longman Group UK Ltd.

Kolapo, Y. (2008). Getting Round the Half-Baked Graduate Syndrome. http://www.punchontheweb.com/Article.apsx?theartic=Art2008110526245

Lessard-Clouston, M. (1997). Language Learning Strategies: An Overview for L2 Teachers. Internet TESL Journal. http://iteslj.org/Articles/Lessard-Clouston-Strategy

Macaro, E. (2006). Strategies for Language Learning and for Language Use: Revising the Theoretical Framework. Modern Language Journal, 90, 320-337. http://dx.doi.org/10.1111/j.1540-4781.2006.00425.x

Nunan, D. (1991). Methods in Second-Language Acquisition Classroom-Oriented Research: A Critical Review. Studies in Second Language Acquisition, 13, 249-174. http://dx.doi.org/10.1017/S0272263100009967

Nwosu-Izuwa, L. U. (2002). Balanced Literacy Development in a Multilingual Environment: The Shared-Reading Teaching Approach. Literacy and Reading in Nigeria, 9, 225-235.

Ogenyi, L. C. (2008b). Reading Proficiency: The Touchstone for Success in Education Reform. Review of Education: Institute of Education Journal, University of Nigeria, Nsukka, 19, 132-143.

O’Malley, J. M., \& Chamot, A. (1990). Learning Strategies in Second Language Acquisition. Cambridge: Cambridge University Press. http://dx.doi.org/10.1017/CBO9781139524490

Onukaogu, C. E. (2002). Reading for the Attainment of Sustainable Democracy. Literacy and Reading in Nigeria, 9, 287298.

Osakwe, N. N. (1998/99). The Nature of Students’ Reading Problems at the Tertiary Level. Literacy and Reading in Nigeria, 8, 138-148.

Otagburuagu, E. J. (1999). English as a Second Language: A Perceptual Approach. Owerri: Intercontinental Educational Books \& Publishers.

Otagburuagu, E. J. (1997). Teaching and Learning the Writing Skill in the English Language: Theories, Issues and Practice. Onitsha: Cape Publisher International Ltd.

Oxford, R. L., \& Burry Stock, J. A. (2008). Strategy Inventory for Language Learning (SILL). http://homepage.wtuc.edu.tw/sill.php

Rivera-Mills, S. V., \& Plonsky, L. (2007). Empowering Students with Language Learning Strategies: A Critical Review of Current Issues. Foreign Language Annals, 40, 535-548. http://ducantian.blog.163.com/blog/216549752007112511016466/

Rodgers, D. M. (2006). Developing Content and Form: Encouraging Evidence from Italian Content-Based Instruction. Modern Language Journal, 90, 373-386. http://dx.doi.org/10.1111/j.1540-4781.2006.00430.x

Steinberg, D. D., \& Sciarini, N. V. (2006). An Introduction to Psycholinguistics (2nd ed.). Harlow: Pearson Longman.

Vandergrift, L. (2003). Orchestrating Strategy Use: Toward a Model of the Skilled Second Language Listener. Language Learning, 53, 463-496. http://dx.doi.org/10.1111/1467-9922.00232

Vandergrift, L. (2006). Second Language Listening: Listening Ability or Listening Proficiency? Modern Language Journal, 9, 6-18. http://dx.doi.org/10.1111/j.1540-4781.2006.00381.x

Woodrow, L. J. (2006). A Model of Adaptive Learning. Modern Language Journal, 90, 297-314. http://dx.doi.org/10.1111/j.1540-4781.2006.00424.x

World Bank (1995). Priorities and Strategies for Education. Washington DC: The International Bank for Reconstruction and Development. 


\section{Appendix}

Table A1. Senior secondary schools used for the study (SSS II students only).

\begin{tabular}{|c|c|c|c|c|c|c|c|c|c|c|c|}
\hline \multirow{2}{*}{$\mathrm{S} / \mathrm{N}$} & \multirow{2}{*}{ Name of school } & \multirow{2}{*}{ Owneship } & \multirow{2}{*}{ State } & \multirow{2}{*}{ Location } & \multirow{2}{*}{ a) No. of stream(s) } & \multirow{2}{*}{ b) $\mathbf{M}$} & \multirow{2}{*}{ c) $\mathbf{F}$} & \multirow{2}{*}{ d) $\mathbf{T}$} & \multicolumn{3}{|c|}{ No. used } \\
\hline & & & & & & & & & $\mathbf{M}$ & $\mathbf{F}$ & $\mathbf{T}$ \\
\hline 1. & $\begin{array}{l}\text { Model Sec. Sch. } \\
\text { Nsukka }\end{array}$ & Govt. & Enugu & Urban & 005 & 106 & 064 & 170 & 95 & 54 & 149 \\
\hline 2. & $\begin{array}{l}\text { Shalom Academy } \\
\text { Nsukka }\end{array}$ & Private & Enugu & Urban & 004 & 070 & 082 & 152 & 63 & 74 & 137 \\
\hline 3.* & $\begin{array}{c}\text { Community Sec. Sch. } \\
\text { Okpatu }\end{array}$ & Govt. & Enugu & Rural & 001 & 023 & 029 & 052 & 23 & 29 & 052 \\
\hline $4 .^{*}$ & $\begin{array}{l}\text { Salvation Commercial } \\
\text { Sec. Sch. Eha-Amufu }\end{array}$ & Private & Enugu & Rural & 001 & 007 & 019 & 026 & 07 & 19 & 026 \\
\hline 5. & $\begin{array}{l}\text { Govt. Tech. Coll. } \\
\text { Abakaliki }\end{array}$ & Govt. & Ebonyi & Urban & 012 & 284 & 142 & 426 & 189 & 101 & 290 \\
\hline $6 .^{*}$ & $\begin{array}{l}\text { Hope High Int'l School } \\
\text { Abakiliki }\end{array}$ & Private & Ebonyi & Urban & 002 & 028 & 022 & 050 & 28 & 22 & 050 \\
\hline 7." & $\begin{array}{l}\text { Model Comprehensive } \\
\text { Secondary School } \\
\text { Umuhuali/Amazu }\end{array}$ & Govt. & Ebonyi & Rural & 002 & 030 & 062 & 092 & 30 & 62 & 092 \\
\hline 8..$^{*}$ & $\begin{array}{l}\text { Comprehensive Sec. } \\
\text { Sch. Ezilo }\end{array}$ & Private & Ebonyi & Rural & 001 & 020 & 021 & 041 & 20 & 21 & 041 \\
\hline 9. & $\begin{array}{c}\text { Development Sec. Sch. } \\
\text { Owerri }\end{array}$ & Govt. & Imo & Urban & 012 & 223 & 197 & 420 & 159 & 123 & 282 \\
\hline $10 .^{*}$ & $\begin{array}{l}\text { Rochers Foundation } \\
\text { Coll. Owerri }\end{array}$ & Private & Imo & Urban & 002 & 045 & 042 & 087 & 045 & 042 & 087 \\
\hline 11. & $\begin{array}{l}\text { Comprehensive Sec. } \\
\text { Sch. Obinze }\end{array}$ & Govt. & Imo & Rural & 003 & 062 & 074 & 136 & 051 & 059 & 110 \\
\hline \multirow[t]{2}{*}{ 12." } & $\begin{array}{l}\text { St Augustine's Model } \\
\text { Sec. Sch. } \\
\text { Amainyi-Ukwu }\end{array}$ & Private & Imo & Rural & 002 & 037 & 048 & 085 & 037 & 048 & 085 \\
\hline & & & & Totals & 047 & 935 & 801 & 1736 & 747 & 654 & 1401 \\
\hline
\end{tabular}

Key: M = Males; F = Females; T = Total. Sources of a)-d): The schools' class registers. ${ }^{*}$ Schools that have less than 100 SSS II students. 